\title{
Religious Freedom and the European Convention on Human Rights: the Case of the Baltic States
}

\author{
SIMON BARNETT
}

Deprivation of [religious liberty] is no slender punishment; it is a heavy price to pay for the exercise of a religious belief. ...

At the end of the nineteenth century my great-grandparents emigrated from Vilnius, Lithuania, to Great Britain, primarily to escape persecution. It was therefore an emotional occasion for me when I visited Vilnius in the summer of 1999. I stayed in the city of Kaunas and viewed the monument to those who died in the concentration camp on the outskirts of the town during the Second World War. It was also my privilege to visit Estonia in October 1999 to attend a conference on 'Law, Religion and Democratic Society' at the University of Tartu and to meet government and religious representatives from all three Baltic states. As a lawyer with a keen interest in religious freedom, especially in the Baltic states, $I$ have written this article in an attempt to clarify what the minimum standards of religious freedom are as promulgated in international law and to ascertain to what extent the Baltic states are meeting those standards.

The Baltic states are emerging from many years of totalitarian oppression. They have the difficult task of drafting and implementing laws which will guarantee fundamental rights and freedoms whilst striving to preserve their respective cultures. Difficulties tend to arise with regard to laws relating to religious freedom, in particular in the context of avoiding potential religious and ethnic conflicts. As I shall show later, the Baltic states have introduced legal provisions on freedom of religion analogous to those granted under the European Convention on Human Rights. In this article I discuss the implications of the European Convention on Human Rights as far as the recognition, registration and tax exemption of religions and religious associations are concerned. I shall show that some countries in Central and Southern Europe, including some which are members of the European Union (EU), are abusing the rights of religious minorities by imposing arbitrary and discriminatory registration and recognition requirements. I shall also show that some other EU countries appear to be consistently breaching the European Convention with regard to the legal status of religious minorities and the rights of individual members of such minorities, despite the fact that these countries also guarantee freedom of religion. I shall discuss the current situation and future prospects in the Baltic states in this wider European context. 


\section{Religious Rights Granted by the European Convention on Human Rights}

Article 9 of the European Convention on Human Rights states that:

(1) Everyone has the right to freedom of thought, conscience and religion; this right includes the freedom to change his religion or belief, and freedom, either alone or in community with others and in public or in private, to manifest his religion or belief, in worship, teaching, practice and observance.

(2) Freedom to manifest one's religion or beliefs shall be subject only to such limitations as are prescribed by law and are necessary in a democratic society in the interests of public safety, for the protection of public order, health or morals, or for the protection of the rights and freedoms of others.

Closely related to Article 9 is the 'parasitic' Article 14. It is parasitic in the sense that it has to be used only in conjunction with one or more of the other Articles in the Convention. Article 14 states that:

The enjoyment of rights set forth in this Convention shall be secured without discrimination on any ground such as sex, race, colour, language, religion, political or other opinion, national or social origin, association with a national minority, property, birth or other status.

Article 9 clearly states that freedom of thought, freedom of conscience and freedom of religion are rights. The freedom to believe, manifest and practise the religion of one's choice is therefore to be enjoyed by all persons, not just by the influential majority.

A number of countries accord public recognition to these fundamental rights but sometimes deny them in practical terms. It is apparent that as far as requirements for religious registration are concerned these countries can be divided into two categories: those countries where registration assists religions to fulfil their objectives; and those countries where registration and tax requirements are used as a tool to restrict the operation of religions. Countries of this second type manifest a differential treatment of religions, in effect viewing religious freedom not as a right but as a privilege for certain dominant religions. One striking example of a country of the second type is Austria.

\section{The Situation in Austria}

Austria has a history of being sparing in its grants of legal status to religions. ${ }^{2}$ Recent changes in legislation have made the necessary criteria more explicit. Some important requirements which according to the 1998 Austrian federal law relating to the legal personality of religious communities ${ }^{3}$ must be fulfilled by religious communities before they can acquire legal status as a state-recognised religion are as follows. For existing applications (under the 1874 Recognition Act) which have not yet been approved the religion must now additionally show that it has existed as a community for ten years since the coming into force of this 1998 law: in other words no current application for legal personality as a state-recognised religion can be granted before at least 2008. For new applications the period is 20 years. During these periods the religions are to be scrutinised by the Ministry of Education and Culture and the Ministry of Finance to see if inter alia they are showing a positive attitude towards the democratic state; what this means is not defined, and could evidently be open to subjective and arbitrary interpretation. Another requirement 
which will adversely affect many of the unrecognised minority religions is that the minimum number of members must be 16,000 (a nominal 0.2 per cent of the population). ${ }^{4}$

Many religions, including the Anglicans, Baptists, Hindus, Seventh-Day Adventists and Jehovah's Witnesses, have been unable to attain legal status in Austria, some with applications to the Austrian government outstanding for many years. The question arises as to whether the restrictions in Austria (and other European countries) are breaching the European Convention. To what extent are restrictions on registration, legal recognition and taxation privileges affecting fundamental human rights?

\section{Religious Restrictions and Compatibility with the European Convention}

Religious freedom and freedom from discrimination based on religion are fundamental rights for everyone, not merely privileges to be enjoyed by the dominant religions. Under Article 9(2) of the Convention, state interference with this fundamental right of freedom of religion is permitted only on very narrowly-defined grounds.

\section{Manifestation}

Firstly, it is only the manifestation of the religion or belief that can be restricted. There is as yet no clear legal definition of what constitutes a 'manifestation', though logically it would have to involve some outward expression of the religious belief or opinion or the performance of religious ritual. ${ }^{5}$ Thus proselytising would count as a 'manifestation', as would any other manner in which religious beliefs or opinions were expressed, whether in public or in private.

If an issue concerning a religion does not involve a question of 'manifestation', then the state cannot apply restrictions allowed for by Article 9(2). What though of mechanisms used by religions to manifest their beliefs where the mechanism is not, of itself, a manifestation? For example, is it a 'manifestation' of religion or belief for a religion to be required to form associations or legal entities? Arguably this is not a manifestation of the religion but a legal requirement of the state for the religion to operate. Certainly the association or legal entity will be used as a mechanism to manifest the religion, but the association or entity itself is a legal requirement, not an expression of religious opinion or belief. Whilst it could be argued that registration requirements are not per se restrictions but merely administrative formalities, the fact is that in many countries some religions are prevented from forming legal entities and in others (such as Austria) are denied personality. It is readily arguable that such restrictions are a fortiori unlawful as the attainment of legal status is not a 'manifestation' under Article 9(2).

The contrary argument, of course, is that if the legal entity is not a 'manifestation' of religion or religious belief then Article 9 does not apply at all. If the members of a religious organisation can still practise their religion without the presence of a legal entity then arguably there is no infringement of Article 9. Possibly these are the submissions that countries such as Austria will use when called on to justify discriminatory practices. However, if these submissions were upheld then highly discriminatory and subjective criteria for forming a religious legal entity would be an indirect but significant way of restricting freedom of religion. Without legal status a religion would find it difficult, if not impossible, to own land, operate bank accounts, 
insure premises and other assets, enter into contracts with public authorities, exercise prison visitation rights and legally protect itself when necessary. Therefore the right to manifest the religion itself would have been significantly affected.

It is also the case that granting legal status to some religions and not others is discrimination based upon the grounds of religion alone and hence is in breach of Article $14 .^{6}$

The European Court of Human Rights has unequivocally stated that religious freedom is one of the foundations of a democratic society: see the case Kokkinakis $v$ Greece. ${ }^{7}$ In the recent case of Serif $v$ Greece ${ }^{8}$ in affirming the judgment on Kokkinakis the court reiterated: 'Freedom of thought, conscience and religion is one of the foundations of a democratic society within the meaning of the Convention. The pluralism indissociable from a democratic society which has been clearly won over the centuries depends on it."

A case on religious registration has yet to be decided by the European Court of Human Rights. However, recent decisions of the European Commission have given the view that religions and religious associations enjoy Article 9 protection. ${ }^{10}$ The court has ruled in Autronic AG v Switzerland" that legal entities can be protected by Article 10 (on freedom of expression). It is to be hoped that the court will follow judgment in the Autronic case with regard to Articles 9 and 14 and will not entertain restrictions on religious freedom outside the provisions of Article 9(2), even if these are indirect restrictions. Freedom of religion must surely mean, or include, the freedom to operate as a religion, to enjoy legal status so that a religion can be both manifested and protected and so that it should not be marginalised in comparison with other religions.

I would submit, then, that restrictions (whether direct or indirect) outside the provisions of Article 9(2) are in breach of the right of every individual to enjoy freedom of religion. The only grounds for restriction are those against 'manifestations' in Article 9(2); these do not include religious beliefs per se, 'a positive attitude toward the government' or a religion's length of existence as valid reasons for restriction of registration or grant of legal personality or tax privileges.

If this is true, the question arises as to how the practices of members of 'dangerous sects' are to be dealt with. One answer is by the use of criminal law. If adherents of a religion are, for example, engaged in tax evasion or are abusing children, the criminal law is there to punish them. However such persons should be punished precisely because they have broken the criminal law and not because they are members of a particular religion. Alternatively, if there is a definite causative link between the religion and criminal behaviour of the members the manifestation of the religion itself can be curtailed under Article 9(2) as being contrary to public order.

\section{Public Order, Health and Morals and the Rights and Freedom of Others}

According to Article 9(2) 'manifestations of religious belief may be restricted in order to protect public order, health or morals, or to safeguard the rights and freedoms of others. The restrictions must be as prescribed in current law, must correspond to a pressing social need and must be necessary in a democratic society. Rather than interpret phrases such as 'public order' or 'public health', the European Court of Human Rights has instead concentrated on a test of 'proportionality' with regard to the restriction in question. ${ }^{12}$ For a restriction to be lawful it must be proportional to the legitimate aim that the restriction is trying to further. In Kokkinakis $v$ Greece the aim of the Greek law in question was inter alia the protection of naive persons from coercive religious proselytism - a legitimate aim, according to a 
majority of the court. However the court, again by a majority, held that Greece had in this case failed the test of proportionality. The imprisoning of an 80-year-old Jehovah's Witness under the proselytism law was out of proportion to the legitimate aim of protecting society. The majority held that the man concerned had not used improper proselytism methods, that there was no evidence of coercion or trickery, and that the subject of his efforts (a cantor's wife) was not particularly naïve. Likewise in Serif v Greece the court held that punishing a Muslim cleric, who had not been appointed by the state, 'for the mere fact that he acted as a religious leader of a group that willingly followed him can hardly be considered to be compatible with the demands of religious pluralism in a democratic society'. ${ }^{13}$

In the light of judgments such as these, it seems that religious restrictions based on the length of time a religious organisation has been in existence or whether it has shown a 'positive attitude towards the democratic state' are going to have to meet a similar test of proportionality.

It is apparent that the tendency in Greece has been to regard fundamental religious rights as privileges to be enjoyed only by members of the dominant churches or by those having the approval of the dominant church. Further evidence for this is provided by the case of Manoussakis v Greece. ${ }^{14}$ The petitioners, Jehovah's Witnesses, had persistently applied for a permit to build a place of worship. The relevant government ministry had consistently delayed a decision, as had the representative of the Greek Orthodox Church who had to give his approval before the permit could be granted. Eventually the petitioners built their place of worship without a permit and were prosecuted. Examination of the Manoussakis case reveals matters of serious concern.

When the application for permission was forwarded to the relevant government department it was then passed (in accordance with Greek government policy) to the Orthodox Church for its approval. No time limit for a decision was set, and there were no criteria for determining objectively whether the permit should be granted at all. It was left therefore to the relevant government department with the assistance of the Orthodox Church to evaluate both the religious beliefs of the applicants and the means by which the applicants expressed these beliefs (through the building of a place of worship). In other words, if the government ministry or the church did not approve of the beliefs of the applicant all they needed to do was refuse the permit or, as in Manoussakis, effectively ignore the petition through delaying tactics.

The European Court of Human Rights unanimously held Greece to be in breach of Article 9. The procedures and measures used, the role of the Orthodox Church, the lack of a time limit for a response and the lack of objective criteria all failed the test of being proportional to the legitimate aim of protecting public order.

The court in Manoussakis held that the state cannot evaluate the religious beliefs of petitioners nor can it decide on the appropriate means of expression for those beliefs. ${ }^{15}$ This decision is of vital importance in reaching an understanding of the degree of restriction which can be imposed under Article 9(2) of the Convention. No government may discriminate against religions on the basis of an evaluation of their beliefs or on the basis of an evaluation of the means by which these beliefs are expressed, such as through a place of worship, apart from those considerations specified explicitly in Article 9(2).

\section{Observations}

Outside the narrow context of Article 9(2) and Article 14 then, the state has no right 
to determine which religions can have legal personality or which religions can enjoy tax exemptions, the reason being that such determinations can be based only on an evaluation of religious belief, the state deciding which religions it 'likes' and which it 'does not like'. In Serif $v$ Greece the court held that tension between competing groups within the same religion was one of the unavoidable consequences of pluralism and that the state's role was 'not to remove the cause of tension by eliminating pluralism, but to ensure that the competent groups tolerate each other'. ${ }^{16}$ The state therefore has a responsibility, indeed a positive duty, to promote tolerance between religious groups rather than causing tension by, in effect, differentiating between 'good' and 'bad' religions.

Similar arguments apply to Article 14 of the Convention which, as noted earlier, when applied together with one or other of the rights granted by the Convention prohibits discrimination on the grounds of religion. Breach of Article 14 will involve an unjustified difference between the treatment of a petitioner and the treatment of persons in an analogous situation to the petitioner. The burden is on the state to show a 'reasonable and objective justification' for such a difference in treatment; differentiation based on religion alone will be held to be in breach of Article 14. ${ }^{17}$ It is therefore difficult to see how countries which impose arbitrary and discriminatory requirements on some religions but not on others can avoid being in breach of Article 14 even if they manage to avoid liability under Article 9.

All that has been said so far does not mean that all restrictions on religion are per se unlawful. The European Court of Human Rights has held that aggressive or coercive proselytism is a 'manifestation' which might lawfully be restricted under Article 9(2). ${ }^{18}$ In Manoussakis the court held that the requirement for a permit to build a place of worship was not of itself a breach of Article 9(2)..$^{19}$ In Serif v Greece the court held that the Greek law which prevented persons from usurping the functions of a minister of a religion was not of itself a breach of Article $9 .{ }^{20}$ In all these cases the restrictions were found to be not unlawful per se; rather it was their mode of application which was out of proportion to the legitimate aim that the restrictions were designed to protect. I would submit, however, that the Austrian requirements for a religion to gain legal personality which are a fortiori outside Article $9(2)$ and 14 are restrictions which are unlawful in themselves as opposed to being merely unlawful in their mode of application.

\section{An Overview of Religious Rights in the Baltic States}

All three Baltic states (Estonia, Latvia and Lithuania) guarantee freedom of religion in their constitutions; ${ }^{21}$ none has a state religion. All three allow for restriction of this fundamental freedom only where the restriction is prescribed by law on the grounds of danger to public health, public order or morals to protect the rights and freedoms of others. ${ }^{22}$ The law in all three states thus closely follows the European Convention on Human Rights.

The three Baltic states allow for all religions to form associations or communities which have legal personality; these have relatively low thresholds for registration. ${ }^{23}$ There are no requirements for a 'positive attitude towards the state' or for a long observation period before legal personality can be granted. There is however some divergence with regard to registration rights and taxation.

In its recent reports the American State Department has not seriously criticised any of the Baltic states for fundamental breaches of religious freedom (Latvia was mentioned for deregistering the Jehovah's Witnesses in 1996; however in October 
1998 they were officially reregistered). On the contrary, such reports indicate that the Baltic states are respecting religious freedom in practice. ${ }^{24}$

\section{Lithuania}

Lithuanian law makes a distinction between traditional (state-recognised) and nontraditional religions, ${ }^{25}$ though individuals are to be treated equally regardless of their religion. ${ }^{26}$ Nontraditional religions can apply for state recognition after 25 years from their initial registration in Lithuaniua. The Lithuanian Parliament has power to grant state recognition after the Ministry of Justice submits an evaluation of the activities of the religious association in question. (There is as yet no standard procedure for carrying out such an evaluation.) State recognition means that registration procedures for the religion in question are more straightforward and that it can receive support from the state. ${ }^{27}$ Newly formed state-recognised religious communities and associations acquire legal personality simply on informing the Ministry of Justice, submitting their governing documents and giving evidence of continuity ${ }^{28}$

Nontraditional religions can also gain legal personality as religious communities (with a minimum of 15 adult Lithuanian citizens) or as religious associations (consisting of a minimum of two religious communities). ${ }^{29}$ The procedure is more complicated than for the state-recognised religions, however. A written request for registration must be submitted, together with the Statute and Statement of Belief of the organisation and a list of members. The Ministry of Justice can evaluate the Statute and activities of the organisation for up to six months after the application, or return the application within $\mathbf{1 5}$ days if the Statute does not comply with procedural requirements. ${ }^{30}$ If the Statute is procedurally correct and the activities of the religion do not violate the laws of Lithuania then the Ministry of Justice shall register the Statute within the six-month period of submission. If the Ministry of Justice refuses registration it shall give the applicants a written notice within five days following the adoption of the decision and specific reasons for refusal must be given. The applicants can then appeal against the decision in court. ${ }^{31}$ When an association is established the process of registering further communities belonging to the association is similar to that of registering communities of the traditional religions.

There are no differences between traditional and nontraditional religions in relation to property rights and religious activity, though traditional religions can receive state aid for the renovation of religious buildings. The tax regime is favourable to all religious communities and associations in Lithuania. Income received for the construction, restoration and repair of religious buildings is free of income tax provided it is used for such purposes. ${ }^{32}$ Religious literature and other necessities imported from outside Lithuania by religious associations or communities are free from customs duty. ${ }^{33}$

Lithuania is committed to incorporating international treaties into national law. ${ }^{34}$

\section{Latvia}

Although the 1995 Law on Religious Organisations does not demand registration of religions, religious organisations can gain certain rights such as legal personality only if they register by submitting the necessary documents to the Department of Public and Religious Affairs. ${ }^{35}$ As in Lithuania, registration can be refused if the documents submitted do not comply with procedural requirements or if the practices or tenets of 
the religion conflict with the laws of Latvia or threaten public order. However, reasons must be given for the refusal that can be challenged in court.

To found a religious community, at least 10 adult Latvian citizens are required. Ten or more communities which have gained registration can then form a religious association. ${ }^{36}$ Registration of the community gives it legal personality. In order to guard against abuse of power by public officials the Latvian Criminal Code states that anyone who interferes with the performance of religious rituals that do not violate public order is liable to a fine of 10 times the average monthly wage or a public reprimand..$^{37}$ Latvia also distinguishes between traditional religions (of which there are currently six) and nontraditional religions, and grants certain privileges to the former such as the right to teach in public schools. Generally religious organisations are exempt from property tax,,$^{38}$ from tax on donations,,$^{39}$ and from tax on receipt of humanitarian aid. However, for nontraditional religions the current practice appears to be that to qualify for tax exemptions they must reapply for tax-exempt status each year.

\section{Estonia}

Estonian law does not distinguish between traditional and nontraditional religions. Indeed, the Constitution specifically advances general equality and nondiscrimination and consequently appears to regard distinguishing between new and old religions as unconstitutional..$^{40}$ All religions are equal before the law and under the 1993 Law on Churches and Congregations religious organisations can (but are not obliged to) register with the Interior Ministry and Board of Religion and must have at least 12 members; the leaders of the religious organisation must be citizens with at least five years' residence in Estonia. Registration gives the organisation legal personality. Provisions on tax exemptions are similar to those in the other two Baltic states.

Estonia specifically incorporates international law and treaties into national law, ${ }^{41}$ and if there is a conflict between the two then international law and treaties shall prevail over national law. ${ }^{42}$

\section{Conclusions}

Under the terms of the European Convention on Human Rights religious freedom is a fundamental right for everyone to enjoy. This right must include freedom to operate as a religion, to gain legal status, to obtain the same tax exemptions as the dominant religions and, as in the Manoussakis case, to own land and buildings, and to manifest religious belief. In the Serif case it was made clear that the state has a responsibility to promote tolerance and harmony between religious groups and to avoid promoting conflict or tension, for example by denying some religions their fundamental rights. Governments must not claim to evaluate the religious beliefs of adherents nor the validity of means of expressing those beliefs, such as in a particular place of worship. If national law demands the formation of religious associations or legal entities then restrictions on formation must at least not breach Article 9(2) and Article 14 of the Convention. If there is differential treatment of religions there is a heavy burden upon the state to prove that any restrictions imposed are necessary for the aims specified in Article 9(2) and that the restrictions imposed are proportional to their legitimate aim. Meanwhile, Article 14 lays a heavy burden on the state to show a 'reasonable and objective justification' for differential treatment. The length of time 
a religion has been in existence or considerations such as whether a religion 'shows a positive attitude towards the democratic state' have no validity in determining whether a religion should be granted registration, legal personality or tax exemptions. According them validity is in breach of Articles 9(1) and 14.

The Baltic states have taken commendable and positive steps towards implementing the spirit and letter of the European Convention. Constitutional guarantees of freedom of religion, low thresholds for forming religious legal entities and generally equal treatment regarding tax exemptions are encouraging signs that the governments of the Baltic states are making strenuous efforts to emerge as true democracies governed by the rule of law.

There is room for improvement in some areas. Consideration needs to be given to the treatment of nontraditional religions in registration and tax exemption procedures. Whilst it is not a breach of the Convention to grant privileges (as opposed to exclusive rights) to traditional religions, differential treatment in matters as fundamental as tax exemptions (Latvia) and registration (Lithuania) might lead to breaches of Articles 9(1) and 14 of the Convention. Much will depend on whether the differential treatment amounts to a restriction not provided for by Article 9(2) or on whether it fails the test of 'reasonable justification' under Article 14. The provision of a more complicated registration procedure for nontraditional religions than for traditional religions is probably not in breach of the Convention provided that there are adequate safeguards to prevent subjective and discriminatory evaluations by government or ecclesiastical officials, such as those revealed in the Manoussakis case. It is apparent that there are safeguards in Lithuania, as the criteria for registration are well established with specific time limits laid down for reply and rights of appeal against the decision. However, the policy in Latvia whereby traditional religions have to reregister for tax-exempt status each year might be in breach of the Convention. It is arguable that this fails the test of proportionality in Article 9(2) and the test of 'reasonable justification' for differential treatment under Article 14.

Vigilance is still required, then; but the fact of the matter is that religious freedom in the Baltic States today is better protected, in both theory and practice, than in some western European countries, including some which are members of the EU.

\section{Notes and References}

Quote from Justice McQuaid re Osier v Osier, 410 a.2d 1027 (Maine 1980).

In the last 120 years only 8 religions have been legally recognised pursuant to the 1874 Recognition Act: the Old Catholic Church; the Herrenhuter Brothers Church; the Methodists; the Mormons; the Armenian Apostolic Church; the New Apostolic Church; the Buddhists and the Syrian Orthodox Church.

3 Bundesgesetzblatt 19/1998.

4 For further details see: 1999 Country Reports on Human Rights Practises (Austria), section 2, part c (Bureau of Democracy, Human Rights, and Labor, US Department of State, 25 February 2000). The report is available on the State Department's website at http://www. stategov

s Kalac v Turkey, case no. 61/1996/680/670, European Human Rights Reports (EHHR), vol. 27, p. 552.

6 Hoffman v Austria, case no. 15/1992/360/434, EHHR, vol. 17, p. 565.

7 Kokkinakis v Greece, case no. 3/1992/348/421, EHHR, vol. 17, p. 397.

8 Serif $v$ Greece, filed as application no. $38178 / 97$ pending final appeal to the Grand Chamber (European Court of Human Rights decision, 14 December 1999.)

9 ibid., paragraph 49. 
10 Kontact-Information-Therapie and Hagen v Austria, no. 11921/86, 57 DR 81 (December 1998), p. 88; A.R.M. Chappell v UK, no. 12587/86, 53 DR 241 (December 1987), p. 246.

1 Ser. A., no. 178 (1990).

12 Kokkinakis v Greece, paragraphs 45-49.

13 Serif v Greece, paragraph 51.

14 Manoussakis v Greece, case no. 59/1995/565/651.

15 Manoussakis v Greece, paragraph 47.

16 Serif v Greece, paragraph 53.

17 Hoffman v Austria.

18 Kokkinakis v Greece, paragraphs 44 and 48.

19 Manoussakis v Greece, paragraph 40.

20 Serif $v$ Greece, paragraph 50.

21 Constitution of Estonia, Article 40; Constitution of Lithuania, Article 26; Constitution of Latvia, Article 99 (Amended 1998).

22 Constitution of Estonia, Article 40(3); Constitution of Lithuania, Article 26(4); Constitution of Latvia, Article 116 (Amended 1998).

23 Estonia: Law on Churches and Congregations, 1993; Lithuania: Law on Religious Communities and Associations, 1995; Latvia: Law on Religious Organisations, 1995.

${ }_{24}$ American State Department, Country Reports on Human Rights Practises, 1996-99.

25 Constitution of Lithuania, Article 43(1).

26 Law on Religious Communities and Associations of the Republic of Lithuania, Article 3.

27 ibid., Article 5. The state recognises nine traditional religions; typically they have been present in Lithuania for $300-400$ years.

28 ibid., Article 10.

29 ibid., Article 11.

30 loc. cit.

31 ibid., Article 12.

32 ibid., Article 16.

33 loc. cit.

${ }^{34}$ Law on International Treaties of the Republic of Lithuania (adopted 26 May 1991), Articles 12 and 14.

35 For a detailed account see Ringolds Balodis, 'Religious organisations in the Latvian state: their rights and obligations', Religion, State and Society, vol. 27, no.2, June 1999, pp. 233-38.

36 Amendment to the law, July 1996.

37 Law on Religious Organisations, Article 138.

${ }_{38}$ Law on Real Estate Tax, 1998.

39 Law on Individual Income Tax, Regulation no. 367.

40 Constitution of Estonia, Articles 12, 11 and 40.

41 Constitution of Estonia, Article 3.

42 ibid., Article 123(2). 